\title{
Product Innovation Efficiency of Russian Electronic Industry: DEA Approach and Cluster Analysis
}

\author{
Vladislav Spitsin \\ Department of Management \\ Tomsk Polytechnic University \\ Tomsk, Russia \\ Spitsin_vv@mail.ru \\ Lubov Spitsina \\ Department of Economics \\ Tomsk Polytechnic University \\ Tomsk, Russia \\ Darya Novoseltseva \\ Tomsk Polytechnic University \\ Tomsk, Russia
}

\author{
Aleksandr Mikhalchuk \\ Department of Higher Mathematics \\ Tomsk Polytechnic University \\ Tomsk, Russia
}

\author{
Nataliya Shabaldina \\ Tomsk State University \\ Tomsk, Russia \\ nataliamailbox@mail.ru
}

Michael Shinkeev

Department of Higher Mathematics

Tomsk Polytechnic University

Tomsk, Russia

schinkeev@tpu.ru

\begin{abstract}
This paper investigates product innovations efficiency in innovative subsection DL «Manufacture of electrical and optical equipment" at the level of Russian regions on the basis of the DEA approach. Leading regions on product innovations efficiency were identified by absolute and relative indicators. We found that only a few regions in Russia are characterized by intensive innovation processes. Most regions lag far behind the leaders on indicators of intensity of innovation processes and innovation efficiency. We proposed and tested cluster analysis method to rank the objects (regions) on their DEA coordinates and to assess the statistical significance of differences between objects.
\end{abstract}

Keywords-innovation efficiency, product innovation, electronic industry, Russian regions, DEA-analysis, cluster analysis, statistics

\section{INTRODUCTION}

Innovations are the important factor of economic and manufacturing growth. But some other significant factors work upon this process. There are also some problems to estimate innovations efficiency, such as the time lag between the moments of idea creation and innovation product market income, innovations discrete and locality. The innovations efficiency can be evaluated for a particular company. The problem is to find innovation efficiency for industrial sector or region using statistical data. Scientists have identified three main approaches to evaluating the efficiency of complex innovation systems [1]:

- Construction of indices and rankings on their basis

The research is made with financial support from Russian Foundation for Humanities (RFH) in the frames of scientific and research project of RFH named "Developing a model of inter-regional cooperation in the field of innovation”, project № 16-02-00492. national or regional innovation systems [2].

- DEA approach. Focused primarily on the assessment of the efficiency of the innovation system as the ratio of outputs and inputs (results and expenses) [3, 4].

- The modeling or econometric approach. This approach is used to analyze the factors affecting the performance of the innovation system. The researchers apply theoretical analysis, mathematical modeling and econometric tests to assess the impact of individual factors [5].

Initially, the researchers focused on the level of national innovation systems. In later studies, the notion of smallersized innovation systems was introduced, such as regional, sectorial, technological, and corporate innovation systems. This paper examines sectorial innovation at the regional level. The object of study is innovative subsection DL «Manufacture of electrical and optical equipment» in Russian regions. The subsection DL «Manufacture of electrical and optical equipment» in Russian manufacturing corresponds with Statistical Classification of Economic Activities in the European Community (NACE Rev. 2) subsections C26 «Manufacture of computer, electronic and optical products» and C27 «Manufacture of electrical equipment» [6]. The problem of Russian manufacturing is low level of innovation activities. Subsection DL is one of the most innovative Russian industries [7] but some innovation effectiveness indicators in DL subsection are several times lower than in foreign countries. For example, speed of product updates (the ratio of production value of new or significantly improved products to total production value) in Russia is $4,5-5 \%$ 
(estimated on the basis of [7] for 2010-2013 data). The leading European countries (Germany, France and Italy) at the same time have $23-31 \%$ (estimated on the basis of Community innovation survey [6] for 2012 data). At the same time for the Russian leading regions innovation effectiveness indicators in subsection DL are comparable with the leading foreign countries. We examined the innovation indicators and the differences between domestic and foreign enterprises for the subsection DL in [8, 9].

In present paper we analyze the efficiency of product innovations using DEA approach and apply cluster analysis to rank the objects (regions) on their DEA coordinates and to assess the statistical significance of differences between objects. We perform cluster analysis according [10] and used software product "Statistics" for calculations. Our research is based on statistical data of subsection DL for Russia and Russian regions [7].

\section{RESEARCH METHODOLOGY}

We applied the DEA method to evaluate the efficiency of innovation separately for absolute and relative indicators. The indicators, which were used for the analysis, are shown in Table I.

TABLE I. IINDICATORS AND THEIR CALCULATIONS

\begin{tabular}{|l|l|l|l|}
\hline $\begin{array}{c}\text { Indicators } \\
\text { type }\end{array}$ & $\begin{array}{l}\text { Features of } \\
\text { efficiency }\end{array}$ & \multicolumn{1}{|c|}{$\begin{array}{c}\text { Indicators and their } \\
\text { calculations }\end{array}$} & Code \\
\hline Absolute & Input (costs) & $\begin{array}{l}\text { Expenditures in innovation } \\
\text { activities }\end{array}$ & EA \\
\hline Absolute & $\begin{array}{l}\text { Output } \\
\text { (results) }\end{array}$ & $\begin{array}{l}\text { Production value of new or } \\
\text { significantly improved products }\end{array}$ & NPA \\
\hline Relative & Input (costs) & $\begin{array}{l}\text { Expenditures in innovation } \\
\text { activities / Total production value }\end{array}$ & ER \\
\hline Relative & $\begin{array}{l}\text { Output } \\
\text { (results) }\end{array}$ & $\begin{array}{l}\text { Production value of new or } \\
\text { significantly improved products / } \\
\text { Total production value }\end{array}$ & NPR \\
\hline
\end{tabular}

a. a. The average values for the period of 2010-2013 years

These indicators data for Russian regions are calculated for 2010-2013 years. Russian regions for the research were included in the sample if its production value of subsection DL was more than 15 billion rubles in 2013 year. Such criterion allowed choosing and examining 30 large regions with significant results. The important fact is that 10 participants of Association of Innovative Regions of Russia (AIRR) [11] are chosen for our research as the regions with significant production value of innovative subsection DL. Regions AIRR in Tables II and III are shown in bold, and in the Fig. 1, 2 - with the relevant red numbers. All AIRR participants (14 Russian regions) position themselves as innovation development leaders in Russia, so high level of subsection DL manufacturing is positive for them.

The research methods:

- DEA-analysis is used to identify the leading regions in absolute and relative indicators.

- Regions' clustering is performed to rank the regions and determining their lag of leaders on the results of DEA-analysis and to assess the statistical significance of differences between regions.
This work is devoted to the product innovations efficiency research at the subsection DL for Russian regions level. The proposed methodology may be used for the innovations efficiency analysis in other subsections of manufacturing oriented on product innovations.

\section{RESUlTS OF DEA AND CLUSTERING ANALYSIS}

The values of absolute and relative indicators of regions are presented in Table II. The results of DEA are shown in Fig. 1,2 .

TABLE II. REgIONS’ COORDINATES IN THE SPACE OF INDICATORS

\begin{tabular}{|c|c|c|c|c|c|}
\hline № & Region & EA & NPA & ER & NPR \\
\hline 1 & Moscow & $3,7 \mathrm{E}+06$ & $5,1 \mathrm{E}+06$ & 1,73 & 2,38 \\
\hline 2 & Saint Petersburg & $2,5 \mathrm{E}+06$ & $4,6 \mathrm{E}+06$ & 1,54 & 2,78 \\
\hline 3 & Moscow region & $3,7 \mathrm{E}+06$ & $3,1 \mathrm{E}+06$ & 4,10 & 3,41 \\
\hline 4 & Kaluga region & $2,4 \mathrm{E}+06$ & $1,2 \mathrm{E}+06$ & 3,13 & 1,56 \\
\hline 5 & Sverdlovsk region & $1,9 \mathrm{E}+06$ & $4,2 \mathrm{E}+06$ & 2,98 & 6,74 \\
\hline 6 & Samara region & $3,3 E+05$ & $1,0 \mathrm{E}+04$ & 0,67 & 2,05 \\
\hline 7 & Nizhny Novgorod region & $7,6 \mathrm{E}+05$ & $1,0 \mathrm{E}+06$ & 2,06 & 2,86 \\
\hline 8 & Perm krai & $1,2 \mathrm{E}+06$ & $1,0 \mathrm{E}+06$ & 3,00 & 2,60 \\
\hline 9 & Republic of Tatarstan & $4,2 \mathrm{E}+05$ & $1,1 \mathrm{E}+06$ & 1,25 & 3,29 \\
\hline 10 & Novosibirsk region & $8,0 E+05$ & $2,0 \mathrm{E}+06$ & 2,58 & 6,41 \\
\hline 11 & Ryazan region & $1,6 \mathrm{E}+06$ & $1,7 \mathrm{E}+06$ & 5,72 & 6,10 \\
\hline 12 & Vladimir region & $9,2 \mathrm{E}+05$ & $1,7 \mathrm{E}+06$ & 2,86 & 5,22 \\
\hline 13 & Chuvash republic & $1,2 \mathrm{E}+06$ & $1,9 \mathrm{E}+06$ & 5,17 & 7,82 \\
\hline 14 & Voronezh region & $4,0 \mathrm{E}+05$ & $8,0 \mathrm{E}+05$ & 2,02 & 4,09 \\
\hline 15 & Kaliningrad region & $5,4 \mathrm{E}+04$ & $9,9 \mathrm{E}+02$ & 0,16 & 0,00 \\
\hline 16 & Chelyabinsk region & $7,4 \mathrm{E}+05$ & $6,5 \mathrm{E}+05$ & 3,11 & 2,73 \\
\hline 17 & Udmurt republic & $7,6 \mathrm{E}+05$ & $7,9 \mathrm{E}+05$ & 3,59 & 3,76 \\
\hline 18 & Tyumen region & $2,3 E+04$ & $3,7 \mathrm{E}+04$ & $\mathbf{0 , 1 0}$ & 0,16 \\
\hline 19 & Saratov region & $9,6 \mathrm{E}+05$ & $1,1 \mathrm{E}+06$ & 4,83 & 5,69 \\
\hline 20 & Yaroslavl region & $2,1 \mathrm{E}+05$ & $8,5 \mathrm{E}+05$ & 1,16 & 4,60 \\
\hline 21 & Pskov region & $1,6 \mathrm{E}+05$ & $2,5 \mathrm{E}+05$ & 0,90 & 1,44 \\
\hline 22 & Republic of Mordovia & $4,7 \mathrm{E}+05$ & $4,5 \mathrm{E}+06$ & 2,98 & 28,40 \\
\hline 23 & Tula region & $1,4 \mathrm{E}+06$ & $1,5 \mathrm{E}+06$ & 9,71 & 10,46 \\
\hline 24 & Penza region & $4,9 \mathrm{E}+05$ & $8,1 \mathrm{E}+05$ & 3,29 & 5,49 \\
\hline 25 & Tomsk region & $9,0 \mathrm{E}+05$ & $2,2 E+06$ & 4,68 & 11,29 \\
\hline 26 & $\begin{array}{l}\text { Republic } \\
\text { Bashkortostan }\end{array}$ & $1,5 E+05$ & $5,3 E+05$ & 0,98 & 3,40 \\
\hline 27 & Smolensk region & $6,7 \mathrm{E}+05$ & $9,3 \mathrm{E}+05$ & 4,23 & 5,88 \\
\hline 28 & Ulyanovsk region & $2,0 \mathrm{E}+05$ & $4,3 E+06$ & 1,15 & 24,56 \\
\hline 29 & Omsk region & $5,0 \mathrm{E}+05$ & $2,5 \mathrm{E}+06$ & 3,65 & 17,74 \\
\hline 30 & Rostov region & $7,0 \mathrm{E}+05$ & $1,1 \mathrm{E}+06$ & 4,51 & 7,37 \\
\hline
\end{tabular}

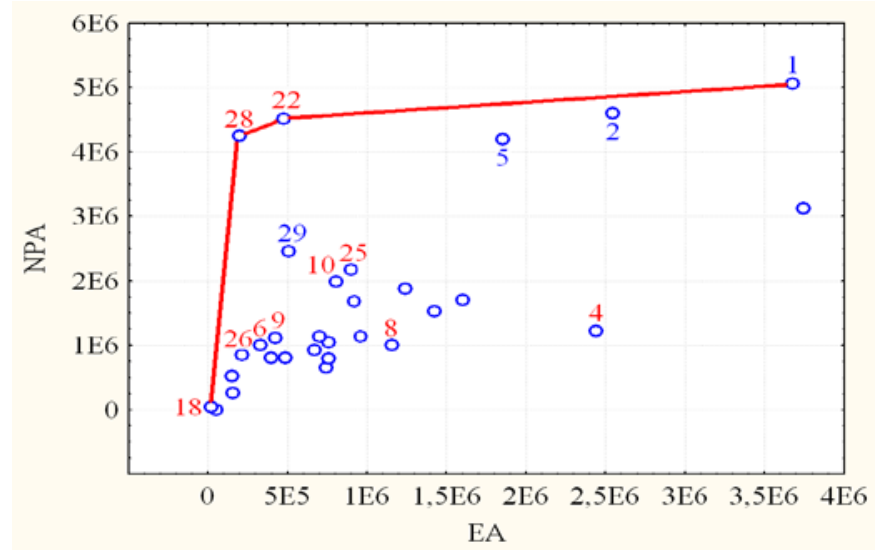

Fig. 1. Results of the DEA-analysis of absolute indicators 
The leaders are Ulyanovsk region (28), the Republic of Mordovia (22), Moscow (1) Tyumen region (18). Note that three of the four leading regions are part of the AIRR. St. Petersburg (2) and the Sverdlovsk region (5) also show high absolute indicators. These data describe the ratio of outputs and inputs for product innovation in absolute terms, but do not characterize the intensity of innovation processes. One of the leaders is Moscow, but it is not a leader due to the intensity of innovation processes. Moscow is a leader due to the size of the economic, industrial and innovation activity.

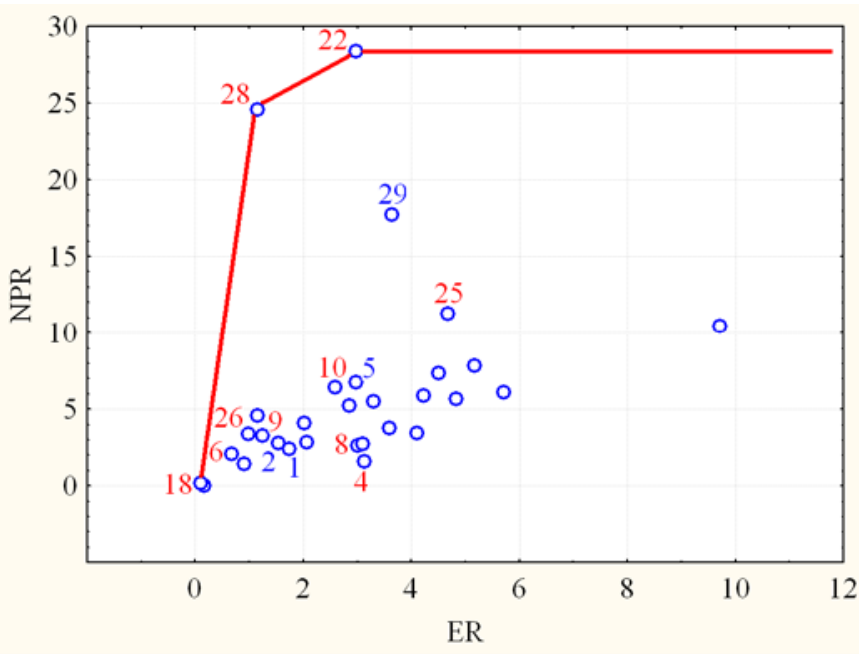

Fig. 2. Results of the DEA-analysis of relative indicators

Ulyanovsk region (28), the Republic of Mordovia (22) and Tyumen region (18) continue to be leaders. All of them are included in AIRR. High indicators also demonstrate Omsk region (29) and Tomsk region (25). The relative indicators of Moscow are low. These findings characterize the intensity of innovation processes in subsection DL on the regional level.

We can conclude that in the process of a comprehensive estimation of innovation efficiency the results of DEA of absolute and relative indicators should complement each other.

One of the unsolved problems of the DEA approach is to assess statistical significance of the differences in ranking objects. DEA approach determines the leaders, but does not assess statistical significance of the lags from leaders and differences between regions. In this paper, we applied cluster analysis to assess the statistical significance of differences between the regions according to their DEA coordinates:

1. First approach. Regions' clustering by their DEA coordinates, which characterize the distance to the optimal borders;

2. Second approach. Regions' clustering by one of their DEA coordinates, which characterize the distance to the nearest optimal border. Another coordinate in this case is taken equal 1.

For clustering regions we applied methods of K-means and hierarchical clustering using association rules (Ward's method) and proximity measures (Euclidean distance). DEA coordinates of regions (EAI, NPAI - first approach, EAII,
NPAII - second approach) and regions' clusters number (CI and CII) are shown in Table III. DEA coordinates of leading regions are equal $(1 ; 1)$. In the first approach we grouped the 30 regions in 13 clusters (Fig. 3 ).

TABLE III. Distribution OF REgIONS IN CLUSTERs By THEIR DEACOORDINATES

\begin{tabular}{|l|l|c|c|c|c|c|c|}
\hline $\mathbf{N} \mathbf{0}$ & \multicolumn{1}{|c|}{ Region } & EAI & NPAI & CI & EAII & NPAII & CII \\
\hline 1 & Moscow & 1 & 1 & 1 & 1 & 1 & 9 \\
\hline 2 & Saint Petersburg & 0,40 & 0,95 & 2 & 1 & 0,95 & 8 \\
\hline 3 & Moscow region & 0,04 & 0,62 & 3 & 1 & 0,62 & 1 \\
\hline $\mathbf{4}$ & Kaluga region & $\mathbf{0 , 0 3}$ & $\mathbf{0 , 2 5}$ & $\mathbf{8}$ & $\mathbf{1}$ & $\mathbf{0 , 2 5}$ & $\mathbf{4}$ \\
\hline 5 & Sverdlovsk region & 0,11 & 0,88 & 5 & 1 & 0,88 & 8 \\
\hline $\mathbf{6}$ & Samara region & $\mathbf{0 , 1 9}$ & $\mathbf{0 , 2 3}$ & $\mathbf{1 1}$ & $\mathbf{1}$ & $\mathbf{0 , 2 3}$ & $\mathbf{4}$ \\
\hline 7 & $\begin{array}{l}\text { Nizhny Novgorod } \\
\text { region }\end{array}$ & 0,09 & 0,23 & 8 & 1 & 0,23 & 4 \\
\hline $\mathbf{8}$ & Perm krai & $\mathbf{0 , 0 6}$ & $\mathbf{0 , 2 2}$ & $\mathbf{8}$ & $\mathbf{1}$ & $\mathbf{0 , 2 2}$ & $\mathbf{4}$ \\
\hline $\mathbf{9}$ & $\begin{array}{l}\text { Republic } \\
\text { Tatarstan }\end{array}$ & $\mathbf{0 , 1 6}$ & $\mathbf{0 , 2 5}$ & $\mathbf{1 1}$ & $\mathbf{1}$ & $\mathbf{0 , 2 5}$ & $\mathbf{4}$ \\
\hline $\mathbf{1 0}$ & $\begin{array}{l}\text { Novosibirsk } \\
\text { region }\end{array}$ & $\mathbf{0 , 1 3}$ & $\mathbf{0 , 4 4}$ & $\mathbf{1 0}$ & $\mathbf{1}$ & $\mathbf{0 , 4 4}$ & $\mathbf{2}$ \\
\hline 11 & Ryazan region & 0,06 & 0,36 & 4 & 1 & 0,36 & 3 \\
\hline 12 & Vladimir region & 0,10 & 0,37 & 4 & 1 & 0,37 & 3 \\
\hline 13 & Chuvash republic & 0,08 & 0,41 & 4 & 1 & 0,41 & 2 \\
\hline 14 & Voronezh region & 0,14 & 0,18 & 13 & 1 & 0,18 & 6 \\
\hline 15 & Kaliningrad region & 0,42 & 0,00 & 7 & 0,42 & 1 & 7 \\
\hline 16 & $\begin{array}{l}\text { Chelyabinsk } \\
\text { region }\end{array}$ & 0,07 & 0,14 & 13 & 1 & 0,14 & 6 \\
\hline 17 & Udmurt republic & 0,07 & 0,17 & 13 & 1 & 0,17 & 6 \\
\hline $\mathbf{1 8}$ & Tyumen region & $\mathbf{1}$ & $\mathbf{1}$ & $\mathbf{1}$ & $\mathbf{1}$ & $\mathbf{1}$ & $\mathbf{9}$ \\
\hline 19 & Saratov region & 0,07 & 0,25 & 8 & 1 & 0,25 & 4 \\
\hline 20 & Yaroslavl region & 0,26 & 0,20 & 9 & 0,26 & 1 & 5 \\
\hline 21 & Pskov region & 0,20 & 0,08 & 12 & 0,20 & 1 & 5 \\
\hline $\mathbf{2 2}$ & $\begin{array}{l}\text { Republic } \\
\text { Mordovia }\end{array}$ & $\mathbf{1}$ & $\mathbf{1}$ & $\mathbf{1}$ & $\mathbf{1}$ & $\mathbf{1}$ & $\mathbf{9}$ \\
\hline 23 & Tula region & 0,06 & 0,33 & 4 & 1 & 0,33 & 3 \\
\hline 24 & Penza region & 0,11 & 0,18 & 13 & 1 & 0,18 & 6 \\
\hline $\mathbf{2 5}$ & Tomsk region & $\mathbf{0 , 1 2}$ & $\mathbf{0 , 4 7}$ & $\mathbf{1 0}$ & $\mathbf{1}$ & $\mathbf{0 , 4 7}$ & $\mathbf{2}$ \\
\hline $\mathbf{2 6}$ & $\begin{array}{l}\text { Republic } \\
\text { Bashkortostan }\end{array}$ & $\mathbf{0 , 2 9}$ & $\mathbf{0 , 1 7}$ & $\mathbf{9}$ & $\mathbf{0 , 2 9}$ & $\mathbf{1}$ & $\mathbf{5}$ \\
\hline 27 & Smolensk region & 0,09 & 0,20 & 8 & 1 & 0,20 & 4 \\
\hline $\mathbf{2 8}$ & Ulyanovsk region & $\mathbf{1}$ & $\mathbf{1}$ & $\mathbf{1}$ & $\mathbf{1}$ & $\mathbf{1}$ & $\mathbf{9}$ \\
\hline 29 & Omsk region & 0,25 & 0,54 & 6 & 1 & 0,54 & 1 \\
\hline 30 & Rostov region & 0,10 & 0,25 & 8 & 1 & 0,25 & 4 \\
\hline & & & & & \\
\hline
\end{tabular}

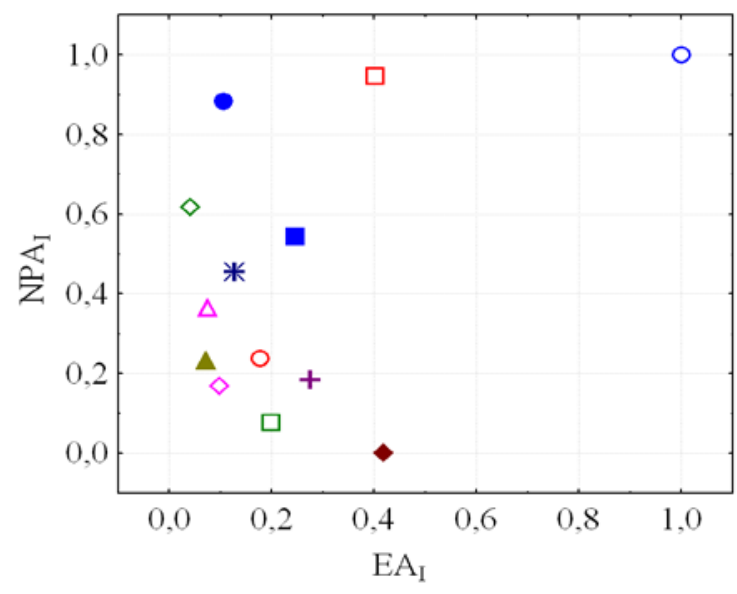

$\circ \mathrm{C}_{\mathrm{I}} \mathrm{l}$

$\square \mathrm{C}_{\mathrm{I}} 2$

$\diamond \mathrm{C}_{\mathrm{I}} 3$

$\triangle \mathrm{C}_{\mathrm{I}} 4$

- $\mathrm{C}_{\mathrm{I}} 5$

- $\mathrm{C}_{\mathrm{I}} 6$

- $\mathrm{C}_{1} 7$

$\triangle \mathrm{C}_{\mathrm{I}} 8$

$+\mathrm{C}_{\mathrm{T}} 9$

* $\mathrm{C}_{\mathrm{I}} 10$

○ $\mathrm{C}_{\mathrm{I}} 11$

ㅁ $\mathrm{C}_{\mathrm{I}} 12$

$\diamond \mathrm{C}_{\mathrm{I}} 13$

Fig. 3. Clustering regions on DEA - coordinates (first approach) 
Leading regions form cluster CI1. F-test shows that the differences between the average values of clusters in their entirety are highly significant (at the level of $0,0005>\mathrm{p}$ ) for each indicator. The smallness of the clusters samples assumes control of the results rank Kruskal-Wallis test, which confirms the findings of F-test in a bit milder form.

In particular, by the variable EAI cluster leaders CI1 highly significantly different from all others, and CI8 is statistically significant (at the level of $0,05>p>0,005$ ) differs from CI11. By variable NPAI cluster leaders CI1 insignificant $(p>0,10)$ differs from CI2, statistically significant $(0,05>p>$ 0,005) - from CI5 and highly significantly - from all others, and CI8 statistically significant $(0,05>p>0,005)$ - from CI13, CI4 and strongly significant $(0,005>p>0,0005)$ - from CI5.

The first approach can be applied to the DEA-models with any number of variables, but it does not correctly evaluate the position of lagging regions and leading regions. For example, St. Petersburg (2), as shown in Fig. 1, is located next to the optimal borders Mordovia (22) - Moscow (1), but in the clustering it is far from the leaders. But analyzing the statistical significance of differences for each variable separately we are solving this problem. As shown above by variable NPAI cluster leaders CI1 insignificant $(p>0,10)$ differs from CI2 (St. Petersburg (2)).

In the second approach we grouped the 30 regions in 9 clusters (Fig. 4).

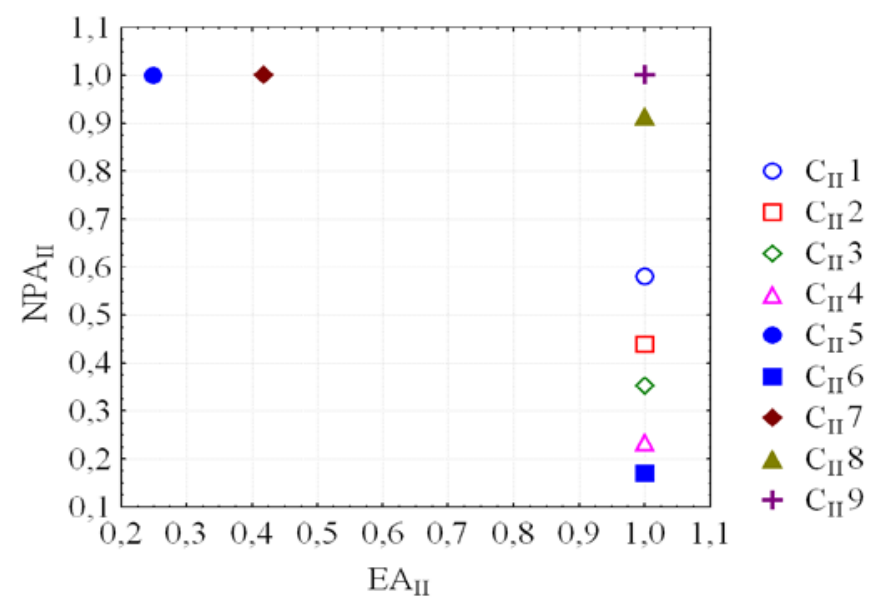

Fig. 4. Clustering regions on DEA - coordinates (second approach)

Leading regions form cluster CII9. By the variable EAII cluster leaders CII9 highly significantly different from all others (CII7 and CII5). By the variable NPAII cluster leaders CII9 is statistically significant differs from CII8 $(p=0,03)$, CII2 $(p=0,01)$ and strongly significant - from CII4 $(p=0,003)$.

The second approach estimates the distance to the nearest optimal border. In this case, St. Petersburg and the Sverdlovsk region form cluster $\mathrm{C} 8$ and they are located close to the leading regions. Other regions lag far behind. These lags correspond to Fig. 1. However, at present time the application of the second approach seems mathematically valid for only one input indicator and one output indicator. Further research may help to develop this approach for more variables.

\section{CONCLUSIONS}

The conducted analysis allows us to make the following conclusions.

1. On the basis of the DEA approach, estimation of product innovations efficiency was carried out for the electronic industry (subsection DL) at the level of Russian regions. Leading regions were identified by absolute and relative indicators of product innovations efficiency.

2. We found that only a few regions in Russia are characterized by intensive innovation processes. Most regions lag far behind the leaders on indicators of the intensity of innovation processes and innovation efficiency.

3. We proposed and tested cluster analysis method to rank the objects (regions) on their DEA coordinates and to assess the statistical significance of differences between objects.

We plan to continue the research of efficiency at the level of sectoral and regional innovation systems with more input and output variables. We are going to develop DEA approach by using cluster analysis method to rank the objects on their DEA coordinates and to assess the statistical significance of differences between objects.

\section{REFERENCES}

[1] Yuezhou Cai Factors, "Affecting the Efficiency of the BRICSs' National Innovation Systems: A Comparative Study Based on Dea and Panel Data Analysis,” Economics Discussion Paper , No. 201152, December 2011. SSRN Journal.

[2] D. Foray and H. Hollanders, "An assessment of the Innovation Union Scoreboard as a tool to analyse national innovation capacities: The case of Switzerland,” Research Evaluation, vol. 24, no. 2, pp. 213-228, Feb. 2015.

[3] J. S. Liu, W.-M. Lu, and M. H.-C. Ho, "National characteristics: innovation systems from the process efficiency perspective," R\&D Management, vol. 45, no. 4, pp. 317-338, Aug. 2014.

[4] M. N. Kotsemir, "Measuring National Innovation Systems Efficiency A Review of DEA Approach,” SSRN Journal.

[5] J.-L. Hu, C.-H. Yang, and C.-P. Chen, "R\&D efficiency and the national innovation system: an international comparison using the distance function approach,” Bulletin of Economic Research, vol. 66, no. 1, pp. 55-71, Dec. 2011.

[6] Eurostat Science and Technology/Community Innovation Survey (2015) [Online]. Eurostat , http://epp.eurostat.ec.europa.eu/portal/page/ portal/statistics/search_database

[7] Unified Interdepartmental Statistical Information System (UniSIS), Russia. WEB: http://www.fedstat.ru/indicators/start.do

[8] V. Spitsin, A. Mikhalchuk, L. Spitsina, N. Shabaldina, and D. Novoseltseva "Clustering of Russian Regions on Indicators of the Product Innovation Efficiency: Case Subsection DL "Manufacture of Electrical and Optical Equipment," 26th International-BusinessInformation-Management-Association Conference, VOLS I - VI, 2015, pp. 589-596, November 2015. WOS: 000366872700061.

[9] V. Spitsin, A. Mikhalchuk, L. Spitsina, N. Shabaldina, and D. Novoseltseva "Comparative Analysis of Economic and Social Results of Foreign and Domestic Firms: Case Russian Electronic Industry," 26th International-Business-Information-Management-Association Conference, VOLS I - VI, 2015, pp. 769-775, November 2015. WOS:000366872700076.

[10] T. Hill, P. Lewicki, "Statistics: Methods and Applications," StatSoft, Tulsa, OK, 2007

[11] Association of Innovative Regions of Russia (2015) [Online], http://www.i-regions.org/en/ 